\title{
A new plesiosaur from the Lower Jurassic of Portugal and the early radiation of Plesiosauroidea
}

Eduardo Puértolas-Pascual, Miguel Marx, Octávio Mateus, André Saleiro, Alexandra E. Fernandes, João Marinheiro, Carla Tomás, and Simão Mateus

Acta Palaeontologica Polonica 66 (2), 2021: 369-388 doi:https://doi.org/10.4202/app.00815.2020

A new plesiosaur partial skeleton, comprising most of the trunk and including axial, limb, and girdle bones, was collected in the lower Sinemurian (Coimbra Formation) of Praia da Concha, near São Pedro de Moel in central west Portugal. The specimen represents a new genus and species, Plesiopharos moelensis gen. et sp. nov. Phylogenetic analysis places this taxon at the base of Plesiosauroidea. Its position is based on this exclusive combination of characters: presence of a straight preaxial margin of the radius; transverse processes of mid-dorsal vertebrae horizontally oriented; ilium with sub-circular cross section of the shaft and subequal anteroposterior expansion of the dorsal blade; straight proximal end of the humerus; and ventral surface of the humerus with an anteroposteriorly long shallow groove between the epipodial facets. In addition, the new taxon has the following autapomorphies: iliac blade with less expanded, rounded and convex anterior flank; highly developed ischial facet of the ilium; apex of the neural spine of the first pectoral vertebra inclined posterodorsally with a small rounded tip. This taxon represents the most complete and the oldest plesiosaur species in the Iberian Peninsula. It is also the most complete, best preserved, and oldest marine vertebrate in the region and testifies to the incursion of marine reptiles in the newly formed proto-Atlantic sea, prior to the Atlantic Ocean floor spreading in the Early Cretaceous.

Key words: Plesiosauria, radiation, Sinemurian, Jurassic, Iberian Peninsula, Europe.

Eduardo Puértolas-Pascual [eduardo.puertolas@gmail.com], GeoBioTec, Faculdade de Ciências e Tecnologia da Universidade Nova de Lisboa, 2829-516 Monte de Caparica, Portugal; Museu da Lourinhã, Rua João Luis de Moura, 95, 2530-158 Lourinhã, Portugal; Aragosaurus-IUCA Research group, Universidad de Zaragoza, Calle Pedro Cerbuna, 12, 50009 Zaragoza, Spain. Miguel Marx [mpmarx1@gmail.com ], Huffington Department of Earth Sciences, ISEM at Southern Methodist University, 75205 Dallas, Texas, USA; GeoBioTec, Faculdade de Ciências e Tecnologia da Universidade Nova de Lisboa, 2829-516 Monte de Caparica, Portugal; Museu da Lourinhã, Rua João Luis de Moura, 95, 2530-158 Lourinhã, Portugal. Octávio Mateus [omateus@fct.unl.pt] and André Saleiro [andresaleiro@gmail.com ], GeoBioTec, Faculdade de Ciências e Tecnologia da Universidade 
Nova de Lisboa, 2829-516 Monte de Caparica, Portugal; Museu da Lourinhã, Rua João Luis de Moura, 95, 2530-158 Lourinhã, Portugal.

Alexandra E. Fernandes [Ae.fernandes@campus.fct.unl.pt], SNSB-Bayerische Staatssammlung für Paläontologie und Geologie, Richard-Wagner-Str., 10, 80333 Munich, Germany; GeoBioTec, Faculdade de Ciências e Tecnologia da Universidade Nova de Lisboa, 2829-516 Monte de Caparica, Portugal; Museu da Lourinhã, Rua João Luis de Moura, 95, 2530-158 Lourinhã, Portugal. João Marinheiro [joaomarinh@gmail.com], Parque dos Dinossauros da Lourinhã, Rua Vale dos Dinossauros, 25, 2530-059 Abelheira, Lourinhã, Portugal; Museu da Lourinhã, Rua João Luis de Moura, 95, 2530-158

Lourinhã, Portugal. Carla Tomás [carla.alex.tomas@gmail.com], Museu da Lourinhã, Rua João Luis de Moura, 95, 2530-158 Lourinhã, Portugal. Simão Mateus[simaomateus@gmail.com], Parque dos Dinossauros da Lourinhã, Rua Vale dos Dinossauros, 25, 2530- 059 Abelheira, Lourinhã, Portugal; Museu da Lourinhã, Rua João Luis de Moura, 95, 2530-158 Lourinhã, Portugal; Faculdade de Letras da Universidade do Porto, Via Panorâmica Edgar Cardoso, 4150-564 Porto, Portugal; GeoBio- Tec, Faculdade de Ciências e Tecnologia da Universidade Nova de Lisboa, 2829-516 Monte de Caparica, Portugal.

This is an open-access article distributed under the terms of the Creative Commons Attribution License (for details please see creativecommons.org), which permits unrestricted use, distribution, and reproduction in any medium, provided the original author and source are credited.

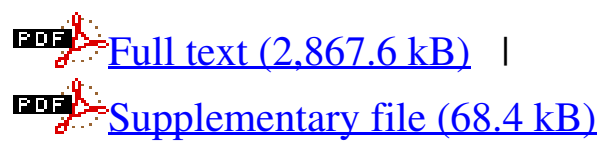

